\title{
Evaluation of Wear in Aftermarket Brake Pads for Enhancing Braking Performance in a Passenger Vehicle
}

\author{
Mohd Zaki Bahrom ${ }^{\#}$, Eida Nadirah Roslin", Muhammad Amir Arzmi", Muhammad Khairuddin Zainal ${ }^{\#}$ \\ ${ }^{\#}$ Automotive Engineering Section, Universiti Kuala Lumpur, Malaysia France Institute, Selangor, Malaysia \\ E-mail: ${ }^{1}$ zakibahrom@unikl.edu.my; ${ }^{2}$ eidanadirah@unikl.edu.my; ${ }^{3}$ amir_arzmi@yahoo.com; ${ }^{4}$ this_boy90@yahoo.com
}

\begin{abstract}
Nowadays, due to the high demands from the independence automotive service centers; there are many aftermarket brake pads available at spare parts shops and sold at reasonable prices. Several types of brake pads are available in the market such as semi-metallic and Non-Asbestos brake pads. The purpose of this study is to evaluate the wear of after-market brake pad performance under the normal driving conditions (highway and non-highway). Three types of aftermarket brake pads that mainly used and sold by independent service shop were selected in this study. The data of the wear in thicknesses losses and weight percentage losses were recorded. The results show that brake pad of non- Asbestos Organic type gives the highest wear loss and create a lot of dust. For semi-metallic brake pad type, the result shows the lowest mass loss. Therefore, it is important to select the suitable type of aftermarket brake pads in order to get balance between cost and quality.
\end{abstract}

Keywords — brake pad; brake pad material; thickness; wear; brake disc; friction materials

\section{INTRODUCTION}

Nowadays, the automotive parts manufacturers are able to offer bundles of high quality products that comparable with the OEM manufacturers. This includes the brake pads market. Generally, brake pads consist of composition of selected materials with their unique friction formula in order to meet the performance criteria of the vehicles. Most of the aftermarket brake pads manufacturers are able to offer high quality or OEM equivalent brake pads with the reasonable prices. Each manufacturer has their unique friction formulas in order to meet the performance criteria of the vehicles. Generally, the manufacturer will not reveal the composition materials of their brake pads due to their proprietary of product information [1]. Due to this reason, only the general information about the material composition in the brake pads will be labelled by the manufacturers. Usually if the brake pad was labelled as semi-metallic, it was composed of semimetallic materials such as carbon-fiber, steel, wool and graphite as lubrications. The ratio of composition would be unknown and different manufacturers will be using their own formulas. It is important to know the formula because it will relates to the friction formulas which are important in measuring the stopping performance as well as producing the low amounts of dust and controlling the engine noise of the vehicle.

The demands on the brake pads are such that they must not decompose or break down in such a way that the friction coefficient with the brake disc is compromised, at high temperatures exhibit a stable and constituent friction coefficient with the brake disc [2].

Basically, the manufacturing of brake pads includes five primary of materials composition with a different function. In addition, the ratios of these compositions vary widely in the different formulations and applications and will contribute to the improvement of braking performances [3-4]. The five primary of materials composition and its application are shown in Fig. 1.

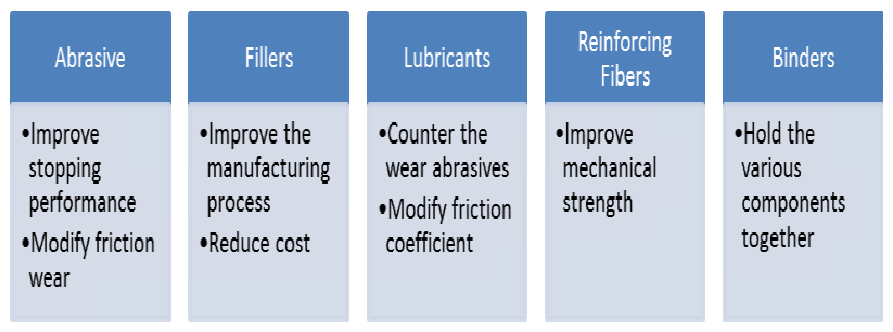

Fig. 1: Example of the Materials Composition in Aftermarket Brake Pad Manufacturing

Since there are many different types of brake pads sold in the market, the users now need to wisely choose the appropriate brake pads to be used in their vehicle not only limited to the pricing aspect but also to have the longer durability or life cycle as well as its effectiveness in improving the braking system of the vehicle. Therefore, this 
paper is aim to provide the information of suitable types of aftermarket brake pads that's available in Malaysia in terms of the wear rate based on the travel distance on highway and non-highway roads. The information provided will be used by the user in selecting their brake pads for their vehicle efficiently.

\section{Methodology}

In this study, three types of brake pads were selected and tested based on the wear rate, durability and also sale price. The types selected as shown in Fig. 2, were non-asbestos organic material NAO, ceramics materials and semi-metallic materials.

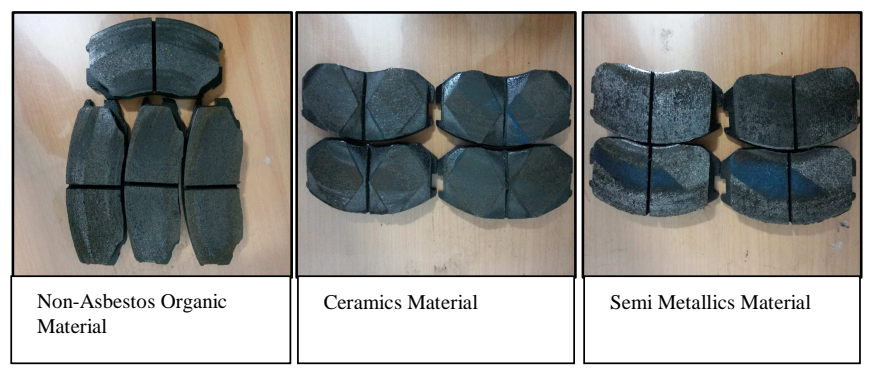

Fig. 2: Types of Brake Pads Used in the Study

\section{A. Wear Measurement}

The wear of brake pads was measured by using vernier caliper. Brake pad wear was measured at each replacement (Fig. 3).
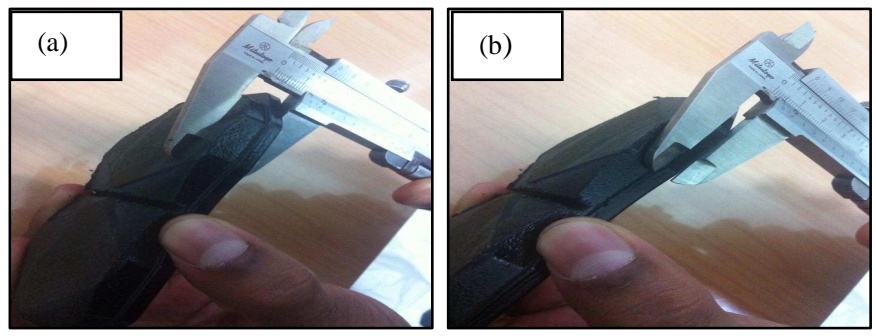

Fig. 3: Vernier caliper is used to measure the brake pads wear (a) measure the thickness of brake pad with backing plate (b) measure thickness of backing plate

\section{B. On Road Performance Test}

The test was conducted by using a local manufactured vehicle A with capacity of $1.3 \mathrm{~L}$. Table 1 shows the specification of vehicle A. The current condition of the braking system was inspected before the test was done. The break performance of Vehicle A was tested on the highway road and non-highway road (city) with the specific driving distance $(50 \mathrm{~km}$ and $100 \mathrm{~km}$ with the average speed of 0 $100 \mathrm{~km} / \mathrm{h})$.

\section{Durability Test}

Each of all selected types of brake pads was installed in Vehicle A. The travel distance was $110 \mathrm{~km}$ for each type. Each type of brake pad was tested at the same road path and the same traffic condition and also at normal driving condition with average speed of $75 \mathrm{~km} / \mathrm{h}$. The mass of brake pad before and after the test was weighted using electronic portable luggage fishing weighing scale $(40 \mathrm{~g}-40 \mathrm{~kg})$ as shown in Fig. 4.

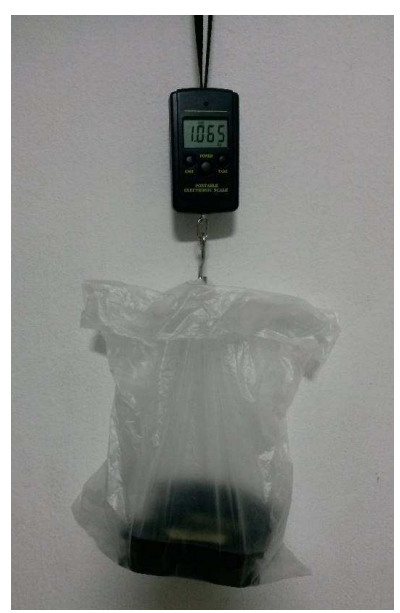

Fig. 4: Weighing Equipment used for weighing the brake pads

TABLE I

VEHICLE SPECIFICATION

\begin{tabular}{|c|c|}
\hline Item & Specification \\
\hline Vehicle System Simulated & Vehicle A 1.3 4G13 Front \\
\hline Engine Capacity & $1,299 \mathrm{cc}$ \\
\hline Wheel Size & 18560 R14 \\
\hline Service Brake & $\begin{array}{l}\text { Type : Double-circuit brake } \\
\text { system, brake booster } \\
\text { Front brakes: Disc brakes } \\
\text { Rear brakes : Drum brakes }\end{array}$ \\
\hline Piston Diameter & $53 \mathrm{~mm}$ \\
\hline Disc diameter $\mathrm{x}$ thickness & $234 \mathrm{~mm} \times 13 \mathrm{~mm}$ \\
\hline Kerb weight & $970 \mathrm{~kg}$ \\
\hline
\end{tabular}

\section{RESULTS AND DISCUSSION}

\section{A. Average Selling Price}

Based on the data collected, the average range of price was between RM40-RM90. Although selling price is one of the important factors to the users in selecting the suitable brake pads for their vehicle, there were other important factors that need to be considered such as the wear of brake pads as well as the durability of the product. In Table 2, the average selling price is shown based on the types of brake pads selected in this study.

TABLE II

Average Selling Price of Brake PADS

\begin{tabular}{|c|c|}
\hline Type of Brake Pads & Average Price (RM) \\
\hline Non Asbestos Organic & 40 \\
\hline Ceramic & 80 \\
\hline Semi-metallic & 90 \\
\hline
\end{tabular}

\section{B. Wear of Brake Pads - Thickness Loss}

The measurement of thickness loss brake pads are listed in Table 3. Based on the test results, Non-asbestos organic brake pad shows the highest thickness loss [5]. Fig. 5 shows the graph of overall test results. 
TABLE III

THICKNESS LOSS FOR 3 TYPES OF BRAKE PADS

\begin{tabular}{|c|c|c|c|}
\hline \multirow{2}{*}{ Test } & \multicolumn{3}{|c|}{ Thickness (mm) } \\
\cline { 2 - 4 } & $\begin{array}{c}\text { Non- } \\
\text { Asbestos }\end{array}$ & Ceramics & $\begin{array}{c}\text { Semi } \\
\text { Metallics }\end{array}$ \\
\hline 1 & 0.13 & 0.07 & 0.04 \\
\hline 2 & 0.15 & 0.08 & 0.07 \\
\hline 3 & 0.13 & 0.08 & 0.06 \\
\hline Average & $\mathbf{0 . 1 3 7}$ & $\mathbf{0 . 0 7 7}$ & $\mathbf{0 . 0 5 6}$ \\
\hline
\end{tabular}

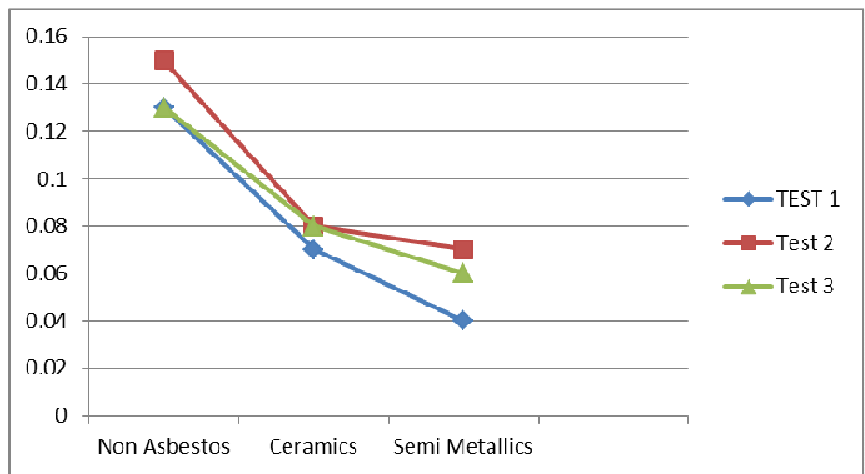

Fig. 5: Graph of Test Results for 3 types of Brake Pads (Thickness Loss)

Non-asbestos friction materials use a blend of different fibers such as aramid, Kevlar, ceramic and glass as replacement for asbestos. These types of brake pads were usually softer and did not create much noise, but tend to wear faster and create a lot of dust. The road condition in city routes was the main factor for the wear rates of nonasbestos organic materials increased. The reason for this condition to be happened was due to the brake system application during traffic light, speed bump, pedestrians, junctions and the speed of other vehicles [6]. Higher thickness loss means shorter brake pad life and thus, incurred more material and maintenance cost. This phenomenon is due to (i) the decomposition of organic materials, (ii) microstructural changes, and (iii) transition of wear mechanism. The degradation of the organic components in the brake pad composition increased with surface temperature and this resulted in the reduction of composition bonding and structure integrity [7]. This process may have increased the rate of surface failure, thus increasing wear rate exponentially, as observed in this work. This finding is similar with the results reported by other researchers [8-9]. By increasing the braking times as well as applied loads resulted in an increase in the surface temperatures. Higher temperatures also caused an extensive plastic flow resulting in the pile-up of deformed material on the worn surface. Subsequently, this material could be sheared off at the edge of the sliding surfaces, resulting in material loss. This could explain why the wear volume in this study increased exponentially with time [8].

The Semi metallic brake pad exhibits the lowest wear rate on the pads routes. The semi-metallic materials use steel wools and porous iron powder as the main constituent $(65 \%$ by weight, where $10-25 \%$ are steel fibres) and bound together with a heat resistant phenolic resins (10\%) and other binder or filler materials. A semi-metallic brake pad is capable to operate at higher temperature, stable friction coefficient, low wear, less squeal, and higher energy absorption [9-11]. Semi metallic brake pad also may wear brake disc/rotors faster and may not function well at low temperatures.

\section{Durability of Brake Pads - Mass Loss}

Highest mass loss in the brake pads indicates the highest composition of softer materials [12]. Based on the study [12], Kevlar fiber (aramide) are also widely used as reinforcing fibers, but they are a different class of fibers such that they are relatively classified as soft fibers. That why Non Asbestos Organic brake pad has the highest mass loss compare to Ceramic and Semi-metallic brake pad. Meanwhile, Semi-Metallic brake pad has the lowest mass loss as the product contain ferrous material that has high resistance to wear. On the other hand, Ceramic brake pad that composes of ceramic fiber an make them to wear a little longer than organic compounds. That why this brake pads is at the intermediate in term of mass loss between Non Asbestos Organic brake pad and Semi-Metallic brake pad. Table 4 shows the overall results for the durability test done in this study. Meanwhile, Fig. 6 shows the total percentage of mass loss for 3 types of brake pads.

TABLE IV

OVERALl RESUlts FOR DURABILITy Test (MASs LOSS)

\begin{tabular}{|l|c|c|c|}
\hline $\begin{array}{l}\text { Type of brake pad/ Mass } \\
\text { of brake pad include the } \\
\text { braking plate }\end{array}$ & $\begin{array}{c}\text { Non } \\
\text { Asbestos }\end{array}$ & Ceramics & $\begin{array}{c}\text { Semi } \\
\text { Metallics }\end{array}$ \\
\hline Total mass before test (g) & 1140 & 1140 & 1280 \\
\hline Total mass after test (g) & 1065 & 1075 & 1230 \\
\hline Total mass loss (g) & 75 & 65 & 50 \\
\hline $\begin{array}{l}\text { Percent mass loss (Total } \\
\text { mass loss/ total mass } \\
\text { before test X 100) }\end{array}$ & $6.57 \%$ & $5.70 \%$ & $3.91 \%$ \\
\hline
\end{tabular}

\section{Percentage Mass Loss for 3 Types of Brake} Pads

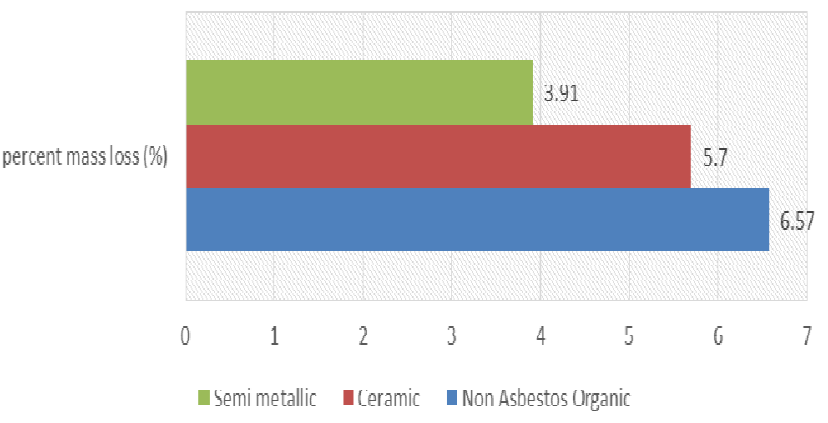

Fig. 6: Graph of Percentage Mass Loss for 3 types of Brake Pads

\section{CONCLUSIONS}

Based on the evaluation of wear for selected types of after-market brake pads in this project, linear measurement methods showed that the brake pads with composition of Non-Asbestos material has the highest loss of thicknesses compared to others. Brake pads with semi-metallic composition showed the lowest mass loss amongst three types of brake pads tested in this study. 
Semi metallic brake pad also has the lowest percentage of mass reduction in durability test. Due to this, it has longer life cycle and will be the best option to the user in selecting the suitable brake pads for their vehicle. Although the selling price of the brake pads is the highest compared to Nonasbestos and Ceramic types of brake pads, the advantage in term of durability in operating at high temperature will be an added advantage to the user selection in order to obtain the optimum level of braking performance for their vehicle.

Determine the right type of after-market brake pads for our vehicle very important in order to get balance between quality and cost. Normally information about brake pads for our vehicle can be done by contacting $\mathrm{OE}$ manufacturing. Unsuitable of after-market brake pad used due high temperature will effect to the brake disc/rotor wear. Exercise brake disc/rotor wear can lead to expensive replacement cost. Brakes are an often-overlooked part of a vehicle, but quality brake parts are essential for safe driving and awe-inspiring performance. From the results, this initial study can be a simple guideline to the users for selecting the suitable types of brake pad for their vehicle and driving conditions.

\section{ACKNOWLEDGMENT}

This project was funded by Universiti Kuala Lumpur Malaysia France Institute. Authors would like to thank all staff at Automotive Engineering Section for their valuable helps and sharing expertise in completing this project.

\section{REFERENCES}

[1] Afiqah O, Fauziana I, Rasid O, and Wong S.V. Elemental Composition Study of Commercial Brake Pads for a Passenger
Vehicle: A Case Study, Recent Advances in Mechanics and Mechanical Engineering, ISBN: 978-1-61804-298-9, 2015.

[2] Imaekhai Lawrance and Ugboya. A. Paul, Ciritcal evaluation/reassessment of (abfm) automotive brake friction materials, Standard Scientific Research and Essays Vol1(11): 275288, November 2013

[3] Blau, P.J., Compositions, Functions and Testing of Friction Brake Materials and Their Additives. A Report by Oak Ridge National Laboratory for U.S. Department of Energy, 2001

[4] P.J Blau, B.C. Jolly, Wear of truck brake lining materials using three different test methods, Wear 259 (2005) 1022-1030

[5] J. kukutschova et al.,Wear mechanism in automotive brake materials, wear debris and its potential environmental impact,Wear 267 (2009)807-817.

[6] P.D.Neis, N.F.Ferreira, F.P.daSilva, Comparison between methods for measuring wear in brake friction materials, 2014.

[7] Masrat Bashir, Sheikh Shahid Saleem, Owais Bashir, International Journal of Research in Engineering and Technology, Friction and wear behavior of disc brake pad material using banana peel powder, Volume: 04 Issue: 02 Febuary 2015.

[8] H. Deng, K.Li, H.Li, P. Wang, J.Xie, L. Zhang, Effect of brake pressure and speed on the tribological properties of carbon/carbon composites with different phrocarbon textures, Wear 270 (2010) 95103

[9] Zhigao, X., and L. Xiaofei. A Research for the Friction and Wear Properties of a Metal-fiber-reinforced Composite Material. Boqun Wu (Eds.). In Mechanical Properties Materials Design 5, Amsterdam: Elsevier Science Publisher. 611-615, 1991

[10] Talib, R. J.; Muchtar, A. \& Azhari C.H., The Performance of SemiMetallic Friction Materials for Passenger Cars, Jurnal Teknologi, Vol. 47(A), pp. 53-72, 2007

[11] Borjesson, M., The Role of Friction Films in Automotive Brakes Subjected to Low Contact Forces, Proceedings of the Institution of Mechanical Engineers, Part C. 1993.

[12] D. Chan and G W Stachowiak. Review of automotive brake friction materials.School of Mechanical Engineering, University of Western Australia, Crawley, Australia, 2014

[13] Yamashita et al, Friction Material For Making Brake Pads, United Stated Pattern, US005266395A, 1993 